\title{
The herbal agent plantamajoside, exerts a potential inhibitory effect on the development of hepatocellular carcinoma
}

\author{
SHU LUO $^{1}$, XING JIANG ${ }^{2}$, GANG YIN $^{3}$, YAJUN LIU ${ }^{4}$, ZHOU LIU $^{1}$, \\ LINGLIAN MENG ${ }^{1}$, JIAN WU ${ }^{5}$ and HAOXIN WU ${ }^{1}$ \\ Departments of ${ }^{1}$ Traditional Chinese Medicine, ${ }^{2}$ Nursing and ${ }^{3}$ Science and Technology, \\ Nanjing University of Chinese Medicine, Nanjing, Jiangsu 210023; ${ }^{4}$ Department of Gastroenterology and \\ ${ }^{5}$ Central Laboratory, Affiliated Hospital of Nanjing University of Chinese Medicine, Nanjing, Jiangsu 210029, P.R. China
}

Received November 5, 2018; Accepted February 11, 2021

DOI: $10.3892 /$ etm.2021.10005

\begin{abstract}
Plantamajoside (PMS), a major component of Plantago asiatica $L$, has several pharmacological properties, including anti-proliferative, anti-inflammatory and anti-tumor effects. However, the effects of PMS on hepatocellular carcinoma (HCC) have yet to be determined. The aim of the present study was to investigate the effects of PMS on HCC and elucidate the underlying mechanism. All assays were conducted using 5 groups, namely control, sorafenib, and PMS 100,50 , and $25 \mu \mathrm{g} / \mathrm{ml}$ groups. Cell proliferation was determined by the MTT assay. Cell migration was evaluated with the wound healing and Transwell assays, respectively. Cell apoptosis and cell cycle distribution were evaluated via flow cytometry. Reverse transcription-quantitative polymerase chain reaction (RT-qPCR) analysis and western blotting were used to further investigate the mechanism of action of PMS. Sorafenib and PMS both significantly attenuated the proliferation and migration of HCC cells, and markedly promoted cell apoptosis. PMS induced cell cycle arrest in the G0/G1 phase. The efficacy of PMS increased in a dose-dependent manner. Further study evaluated the expression of peroxisome proliferator-activated receptor (PPAR $\gamma$ ), nuclear factor (NF)- $\kappa \mathrm{B}$ and cyclooxygenase (Cox-2) using RT-qPCR analysis and western blotting. The results demonstrated that PMS promoted the expression of PPAR $\gamma$ and suppressed the expression of NF- $\kappa$ B and Cox-2. In conclusion, PMS was shown to affect cell proliferation, migration, apoptosis and cell cycle distribution. Furthermore, PMS promoted the expression of PPAR $\gamma$ and inhibited the expression of NF- $\kappa \mathrm{B}$ and Cox -2 , which may be the mechanism underlying its biological effects. Based on the results of the present study, PMS appears to be a promising agent for HCC therapy.
\end{abstract}

Correspondence to: Dr Yajun Liu, Department of Gastroenterology, Affiliated Hospital of Nanjing University of Chinese Medicine, 155 Hanzhong Road, Qinhuai, Nanjing, Jiangsu 210029, P.R. China E-mail: nzy_lyj@163.com

Key words: plantamajoside, hepatocellular carcinoma, herbal medicine, peroxisome proliferator-activated receptor $\gamma$

\section{Introduction}

Hepatocellular carcinoma (HCC) is an aggressive cancer and is the third leading cause of cancer related mortality worldwide (1). A number of patients with HCC are not considered candidates for surgery due to the late stage diagnosis (2) and HCC is highly resistant to chemo therapy (3). Therefore, novel drugs and treatment targets are urgently needed to develop therapies for HCC.

Peroxisome proliferator-activated receptor $\gamma(\operatorname{PPAR} \gamma)$ is a class of ligand activated nuclear transcription factor. Upon activation by its ligand, PPAR $\gamma$ can inhibit tumor cell proliferation and metastasis, as well as promote apoptosis $(4,5)$. For example, activated PPAR $\gamma$ promotes the expression of the pro-metastatic genes MMP9, MMP13 to regulate cell metastasis; overexpression of PPAR $\gamma$ also promotes expression of caspase-3, caspase-7 and other caspases $(6,7)$. Previous studies have also indicated that PPAR $\gamma$ transcriptionally inhibits $\mathrm{NF}-\kappa \mathrm{B}$ signaling in HCC $(8,9)$. Cyclooxygenase-2 (Cox-2), a prostaglandin synthetase, is a rate-limiting enzyme that is highly expressed in various types of cancer, including HCC, and exerts anticancer effects (10). The promoter region of Cox- 2 contains several known sequences, including a binding site for $\mathrm{NF}-\kappa \mathrm{B}$ (11).

Plantamajoside (PMS) is a major component of Plantago asiatica $L$, which has several pharmacological properties, including anti-proliferative, anti-inflammatory and anti-tumor effects $(12,13)$. Previous studies have reported that PMS suppresses the growth and metastasis of breast cancer and squamous cell carcinoma $(14,15)$. Furthermore, it has been reported that the biological effects of PMS are mediated through the regulation of MMP9 and 2; NF- $\kappa \mathrm{B}$; PI3K/Akt; and MAPK signaling $(13,15-17)$.

To the best of our knowledge, the present study is the first study that has demonstrated that PMS inhibits the biological functions of HCC cells and as such, may be employed as a novel therapeutic agent for human HCC.

\section{Materials and methods}

Reagents. PMS was purchased from Shifeng Biological Technology Co., Ltd., and dissolved in a solution of ethanol 
and double distilled water at a ratio of 1:1. Sorafenib (10 mM) was purchased from Selleck Chemicals to be used as positive control and was digested in a solution containing DMSO $\left(63 \mathrm{mg} / \mathrm{ml}\right.$, warmed to $\left.25^{\circ} \mathrm{C}\right)$. T0070907 was purchased from Selleck Chemicals. It has been previously reported that T0070907 is a selective ligand for PPAR $\gamma$, functioning as an antagonist (18).

Cell culture and treatment. Huh7 cells, PLC/PRF 5 and THLE-2 cells (The Cell Bank of Type Culture Collection of Chinese Academy of Sciences) were cultured in DMEM (Gibco; Thermo Fisher Scientific, Inc.) containing 10\% FBS (Gibco; Thermo Fisher Scientific, Inc.) at $37^{\circ} \mathrm{C}$ in an atmosphere containing $5 \% \mathrm{CO}_{2}$. Cells were treated with PMS at a concentration of 25,50 or $100 \mu \mathrm{g} / \mathrm{ml}$ according to a previous study (14), or were treated with sorafenib at 5 or $20 \mu \mathrm{M}$. T0070907 was used as a pre-treatment to inhibit PPAR $\gamma$.

Cell viability assay. To investigate the effects of PMS on cell growth, MTT assays were used. Huh7 cells were seeded in 96-well plates at a density of $1 \times 10^{4}$ cells/well for $24 \mathrm{~h}$. After cell attachment, the cells were treated with sorafenib or PMS at 25,50 or $100 \mu \mathrm{g} / \mathrm{ml}$, or were not treated at $37^{\circ} \mathrm{C}$. The Optical density (OD) value at $490 \mathrm{~nm}$ was detected at 12,24 , 36 and $48 \mathrm{~h}$.

Wound healing assay. Cells ( $1 \times 10^{6}$ cells/well) were seeded in 6-well plates and incubated for $48 \mathrm{~h}$ until $\sim 100 \%$ confluent. Cells were washed with serum-free medium and pre-treated with mitomycin $\mathrm{C}\left(10 \mu \mathrm{g} / \mathrm{ml}\right.$ at $37^{\circ} \mathrm{C}$ for $30 \mathrm{~min}$ ). Subsequently, the incubation medium was replaced with serum-free DMEM. A scratch was created in the cell layer using a $200 \mu \mathrm{l}$ pipette tip, followed by incubation with medium (non-treated control), sorafenib (positive control) or PMS at 25,50 or $100 \mu \mathrm{g} / \mathrm{ml}$ for $48 \mathrm{~h}$. Cell migration was examined under a light microscope (magnification, x100; Olympus Corporation). The wound healing distance was calculated using the following equation: (Initial width at $0 \mathrm{~h}$-final width at 48$) / 0 \mathrm{~h}$ width. The relative wound healing distance was obtained by normalizing to the control group.

Transwell assay. Cells were seeded at a density of $1 \times 10^{4}$ cells/well in the upper chamber of a transwell plate ( $8 \mu \mathrm{m}$ pore-size filter; Merck KGaA) and received no treatment (control), were treated with sorafenib (positive control) or were treated with PMS at 25,50 or $100 \mu \mathrm{g} / \mathrm{ml}$ at $37^{\circ} \mathrm{C}$ for $48 \mathrm{~h}$. Following addition of $100 \mu \mathrm{l} \mathrm{FBS}$ free medium and treatment with mitomycin $\mathrm{C}$ at $37^{\circ} \mathrm{C}$ for $30 \mathrm{~min}$, the upper chambers were placed in a 24-well plate. The lower chambers were filled with $500 \mu \mathrm{l}$ medium supplemented with $10 \%$ FBS for $24 \mathrm{~h}$. The cells that had migrated to the lower surface of the filter were stained with $0.1 \%$ crystal violet solution. Images were captured using a light microscope (magnification, x100; Olympus Corporation) and processed by IPP 6.0 software (Media Cybernetics, Inc.).

Cell apoptosis and Cell cycle. Cells $\left(4 \times 10^{4}\right.$ cells/well) were cultured with sorafenib and PMS at 25,50 and $100 \mu \mathrm{g} / \mathrm{ml}$ for $48 \mathrm{~h}$ prior to analysis. The cells were subsequently fixed with $70 \%$ pre-cooled ethanol for $12-14 \mathrm{~h}$, washed with PBS and resuspended in PBS containing RNase and PI/Triton X-100 $(20 \mu \mathrm{g} / 0.1 \%$ Triton $\mathrm{X}-100)$ for $15 \mathrm{~min}$ at $37^{\circ} \mathrm{C}$, then the cell cycle was analyzed ( $1 \times 10^{4}$ cells/sample) using the BD AccuriC6 flow cytometer (BD Biosciences).

Cells were cultured with sorafenib and PMS at 25,50 and $100 \mu \mathrm{g} / \mathrm{ml}$ for $48 \mathrm{~h}$ prior to analysis, stained with the Annexin V-FITC Apoptosis Detection kit (Beyotime Institute of Biotechnology) according to manufacturer's instructions and cell apoptosis was detected using the BD AccuriC6 flow cytometer (BD Biosciences). Data on the cell cycle distribution and cell apoptosis were further analyzed using FlowJo software (version 10; FlowJo LLC).

Reverse transcription-quantitative PCR (RT-qPCR) analysis. Total RNA was extracted from Huh7 cells using TRIzol ${ }^{\circledR}$ (Invitrogen; Thermo Fisher Scientific, Inc.) following the manufacturer's instructions. RNA concentrations were evaluated using a spectrophotometer (Beckman Coulter, Inc.). cDNA was synthesized using a Reverse Transcription kit (Applied Biosystems; Thermo Fisher Scientific, Inc.) according to the manufacturer's instructions manual. The temperature protocol for RT was as follows: $37^{\circ} \mathrm{C}$ for $15 \mathrm{~min}$, followed by $85^{\circ} \mathrm{C}$ for $5 \mathrm{sec}$ and holding at $4^{\circ} \mathrm{C}$. cDNA was amplified by PCR using SYBR (Invitrogen; Thermo Fisher Scientific, Inc.), and the specific primers used were as follows: GAPDH (reference gene) forward, 5'-GAACGGGAAGCT CACTGG-3' and reverse, 5'-GCCTGCTTCACCACCTTC T-3; NF- $\kappa$ B forward, 5'-AAGCACGAATGACAGAGGC-3' and reverse, 5'-CTTGGCGGATTAGCTCTTTT-3'; Cox-2 forward, 5'-TGTGCAACACTTGAGTGGCT-3' and reverse, 5'-ACTTTCTGTACTGCGGGTGG-3'; and PPAR- $\gamma$ forward, 5'-GCAGGAGCAGAGCAAAGAG-3' and reverse, 5'-GAG GAGAGTTACTTGGTCGTTC-3'. The thermocycling conditions were as follows: $95^{\circ} \mathrm{C}$ for $2 \mathrm{~min}$, followed by 40 cycles of $95^{\circ} \mathrm{C}$ for $20 \mathrm{sec}$ and $65^{\circ} \mathrm{C}$ for $40 \mathrm{sec}$. Expression levels of target genes were normalized to the endogenous control GAPDH using the $2^{-\Delta \Delta C q}$ method (19).

Western blotting. Cells $\left(1 \times 10^{6}\right.$ cells/well $)$ were seeded into 6-well plates and received no treatment (control) or were treated with sorafenib (positive control) and PMS at 25,50 or $100 \mu \mathrm{g} / \mathrm{ml}$ for $48 \mathrm{~h}$. Cells were lysed using lysis buffer (Shanghai Yanjin Biological Technology Co., Ltd.) and the protein concentration was detected using spectrophotometry. Equal masses of protein samples (30 $\mu \mathrm{g}$ extract loaded per lane) were subjected to $12 \%$ SDS-PAGE transferred to PVDF membranes (Invitrogen; Thermo Fisher Scientific, Inc.). After blocking with 5\% non-fat milk at room temperature for $2 \mathrm{~h}$, samples were incubated with the indicated primary antibody, namely; NF- $\mathrm{kB}$ (p65; cat. no. MW 65; 1:1,000; Cell Signaling Technologiy, Inc.), Cox-2 (cat. no. MW 74; 1:1,000; Cell Signaling Technology, Inc.), PPAR- $\gamma$ (cat. no. MW 55; 1:1,000; Cell Signaling Technologies, Inc.), MMP2 (cat. no. MW 72; 1:1,000; Cell Signaling Technology, Inc.), MMP9 (cat. no. MW 92; 1:1,000; Cell Signaling Technology, Inc.), cyclin D1 (cat. no. MW 36; 1:1,000; Cell Signaling Technology, Inc.), cleaved-caspase-3 (cat. no. MW 35, 1:1,000; Cell Signaling Technology, Inc.), caspase-3 (cat. no. MW 17; 1:1,000; Cell Signaling Technology, Inc.), cytochrome C (Cyt-C; cat. no. MW 14; 1:1,000; Cell Signaling 

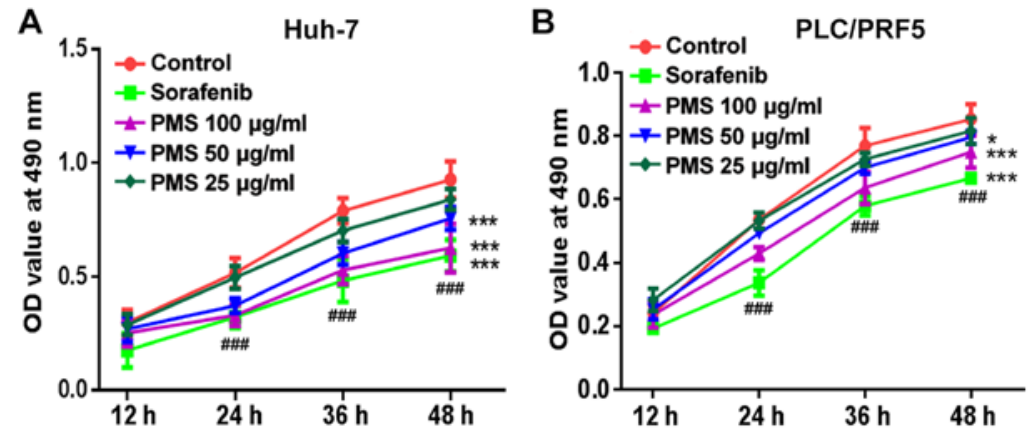

Figure 1. Cell viability decreases after treatment with PMS. Cell viability of (A) Huh 7 and (B) PLC/PRF5 cells was analyzed using MTT assays at $12,24,36$ and $48 \mathrm{~h}$ after treatment with 25,50 and $100 \mu \mathrm{g} / \mathrm{ml}$ PMS. Sorafenib was used as a positive control and non-treated cells were used as control. Data are presented as mean $\pm \mathrm{SD} .{ }^{*} \mathrm{P}<0.05,{ }^{* * *} \mathrm{P}<0.001$ vs. the control group; ${ }^{\# \#} \mathrm{P}<0.001$ vs. the control group. OD, optical density; PMS, plantamajoside.

Technology, Inc.), GAPDH (cat. no. MW 37; loading control, 1:1,000; Cell Signaling Technology, Inc.). Subsequently, the target proteins were evaluated by binding with horseradish peroxidase-conjugated anti-rabbit (cat. no. ab205718; 1:10,000) or an anti-mouse (cat. no. ab205719; 1:10,000; both Abcam) secondary antibodies and an ECL kit (Wuhan Servicebio Technology Co., Ltd.). Gray scale scanning was used to analyze the protein bands.

Statistical analysis. Graphpad PRISM 6.0 (GraphPad Software, Inc.) was used to analyze the data. Numerical results are presented as the mean $\pm \mathrm{SD}$ from three independent experiments. Differences between groups were compared using one-way ANOVAs and two-way ANOVAs, followed by Tukey's post-hoc multiple comparisons tests. A P-value $<0.05$ was considered to indicate statistically significant differences.

\section{Results}

PMS inhibits the viability of HCC cells. To investigate the anti-HCC effect, Huh7 and PLC/PRF5 cells were treated with PMS at various doses and MTT assays were performed to determine cell viability. Sorafenib, as a positive control, significantly reduced the viability of Huh7 and PLC/PRF5 cells at all measured time-points. PMS, at $100 \mu \mathrm{g} / \mathrm{ml}$, also exhibited a similar efficacy to sorafenib in Huh7 and PLC/PRF5. PMS at $50 \mu \mathrm{g} / \mathrm{ml}$ also showed a significant reduction in the cell viability at $48 \mathrm{~h}$ in Huh7 and PLC/PRF5 cells compared with the untreated control, but the treatment in PLC/PRF5 did not show the same level of significance as that in Huh7 cells. In addition, PMS at $25 \mu \mathrm{g} / \mathrm{ml}$ did not exhibit a significant impact compared with the untreated control in both HCC cells, only having a significant impact on the PCL/PRF5 cells at $48 \mathrm{~h}$ (Fig. 1). PMS at $100 \mu \mathrm{g} / \mathrm{ml}$ promoted the expression of mRNA and proteins of PPAR $\gamma$ in the Huh7 and PLC/PRF5 cell line compared with the control group (Fig. 2). The cell viability of Huh-7 and PLC/PRF5 cells, which was reduced by Sorafenib and $100 \mu \mathrm{g} / \mathrm{ml}$ PMS, was reversed by the PPAR $\gamma$ inhibitor, T0070907 when compared with PMS $100 \mu \mathrm{g} / \mathrm{ml}$ (Fig. 3). PPAR $\gamma$ may be a potential mechanism by which PMS exerted its anti-tumor effects.

HCC cell migration is inhibited by PMS. As shown in Fig. 4, wound healing assays showed a significant decrease in the cell migration in the sorafenib and PMS $100 \mu \mathrm{g} / \mathrm{ml}$ groups compared with the untreated cells, with no significant difference being found between these two treatments. PMS $50 \mu \mathrm{g} / \mathrm{ml}$ caused a significant reduction in the cell migration in both cells. The low dose group (PMS $25 \mu \mathrm{g} / \mathrm{ml}$ ) did not exhibit a notable change compared with the untreated control group. To further investigate whether PPAR $\gamma$ participated in the effects of PMS, transwell assays were performed and it was demonstrated that 50 and $100 \mu \mathrm{g} / \mathrm{ml}$ PMS markedly inhibited cell migration compared with the untreated control group, and that treatment with the PPAR $\gamma$ inhibitor, T0070907, reversed the effects of PMS on cell migration compared with $100 \mu \mathrm{g} / \mathrm{ml}$ PMS (Fig. 5).

PMS induces cell cycle arrest at the G0/G1 phase and promotes apoptosis in HCC cells. To further investigate the effects of PMS on cell proliferation, the cell cycle was analyzed in Huh-7 and PLC/PRF5 cells. It was found that there were significantly more cells in the G0/G1 phase in the sorafenib, PMS $100 \mu \mathrm{g} / \mathrm{ml}$ and PMS $50 \mu \mathrm{g} / \mathrm{ml}$ treated groups compared with the untreated control group. The effect of PMS on the cell cycle appeared to be directly associated with the dose administered. Cell cycle arrest at the G0/G1 phase was reversed by treatment with T0070907 (Fig. 6).

In addition, cell apoptosis in Huh-7 and PLC/PRF5 cells was significantly enhanced by PMS and sorafenib treatment. PMS at a high dose $(100 \mu \mathrm{g} / \mathrm{ml})$ exerted effects comparable to those of sorafenib and the efficacy of PMS was directly associated with the dose administered, that is, the higher the dose of PMS, the stronger the promotive effect on apoptosis. The raised apoptosis observed following PMS $100 \mu \mathrm{g} / \mathrm{ml}$ treatment to both cell lines was significantly reversed by treatment with a PPAR $\gamma$ inhibitor (T0070907) in both cell lines, although this did not reach levels observed in the untreated cells (Fig. 7).

Further mechanisms of PMS on cell migration, proliferation, the cell cycle and cell apoptosis. To further confirm that the effects of PMS on cell migration, proliferation, the cell cycle and cell apoptosis are PPAR $\gamma$-dependent, the expression levels of biomarkers involved in the above processes including MMP2, MMP9, Cyclin D1, cleaved caspase-3/caspase-3 and Cyt-C were detected (Fig. 8). MMPs play a role in the degradation of the extracellular matrix, leading to metastasis (20). 


\section{A}

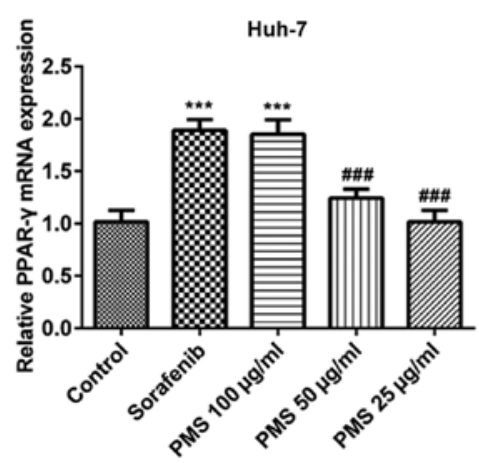

B
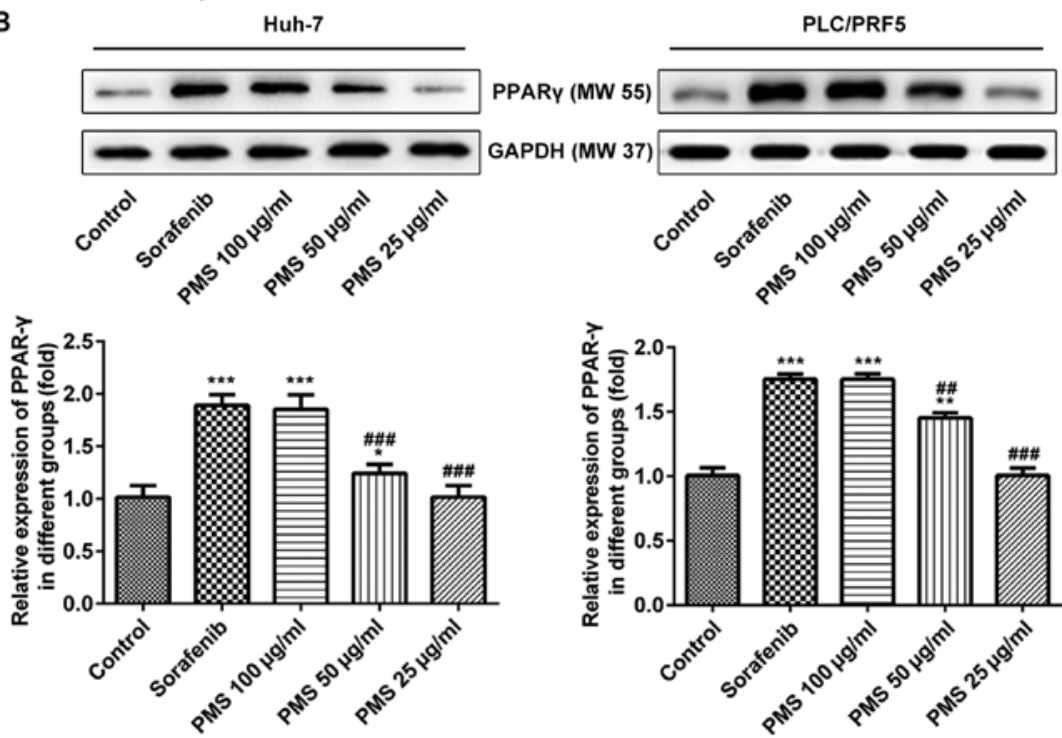

Figure 2. PMS affects PPAR $\gamma$ expression levels in HCC cells. (A) Reverse transcription-quantitative PCR and (B) western blotting were used to analyze the expression levels of PPAR $\gamma$ after treatment with sorafenib or the various concentrations of PMS in Huh-7 and PLC/PRF5 cells. Sorafenib was used as a positive control and non-treated cells were used as control. Data are presented as the mean $\pm \mathrm{SD}$. ${ }^{*} \mathrm{P}<0.05,{ }^{* *} \mathrm{P}<0.01,{ }^{* * * *} \mathrm{P}<0.001$ vs. the untreated control group; ${ }^{\# \# /} \mathrm{P}<0.01$, ${ }^{\# \# \# P} \mathrm{P}<0.001$ vs. sorafenib. PMS, plantamajoside; PPAR $\gamma$, peroxisome proliferator-activated receptor $\gamma$.
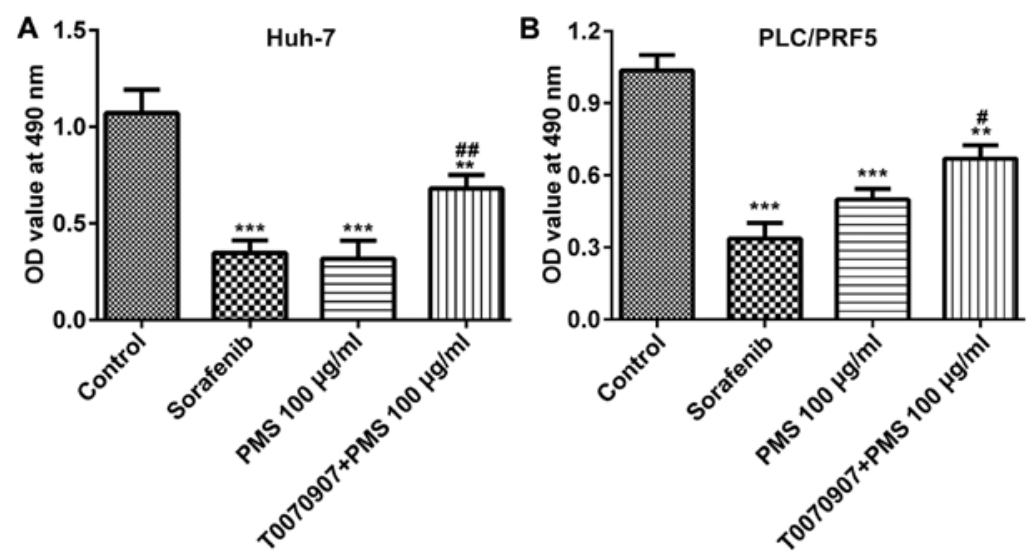

Figure 3. PPAR $\gamma$ reverses the effects of PMS on cell viability. Cell viability of (A) Huh-7 and (B) PLC/PRF5 following treatment with sorafenib, PMS or T0070907 + PMS for $48 \mathrm{~h}$. Data are presented as the mean $\pm \mathrm{SD} .{ }^{* *} \mathrm{P}<0.01,{ }^{* * *} \mathrm{P}<0.001$ vs. the control group; ${ }^{\# P} \mathrm{P}<0.05,{ }^{\sharp \#} \mathrm{P}<0.01 \mathrm{vs}$. PMS $100 \mu \mathrm{g} / \mathrm{ml}$. PMS, plantamajoside; T0070907, PPAR $\gamma$ inhibitor.

Consistently, the expression levels of MMP2 and MMP9 were significantly decreased in the sorafenib and PMS $100 \mu \mathrm{g} / \mathrm{ml}$ treated groups, compared with the untreated control. The PPAR $\gamma$ inhibitor, T0070907 reversed the inhibitory effect of PMS. Cyclin D1, a major cell cycle regulators of G1 phase progression (21), was expressed at significantly lower levels in the sorafenib, PMS $100 \mu \mathrm{g} / \mathrm{ml}$ and PMS $50 \mu \mathrm{g} / \mathrm{ml}$ treated groups, than in the control. Again, the effects of PMS on the expression levels of cyclin D1 were significantly reversed by T0070907. In regards to apoptosis related proteins, caspase-3 and Cyt-C are involved in apoptosis activation (22). The expression levels of cleaved-caspase-3, a compound caused by the activation of caspase- 3 activation (22), were significantly increased in the sorafenib and PMS 100 and $50 \mu \mathrm{g} / \mathrm{ml}$ 
A
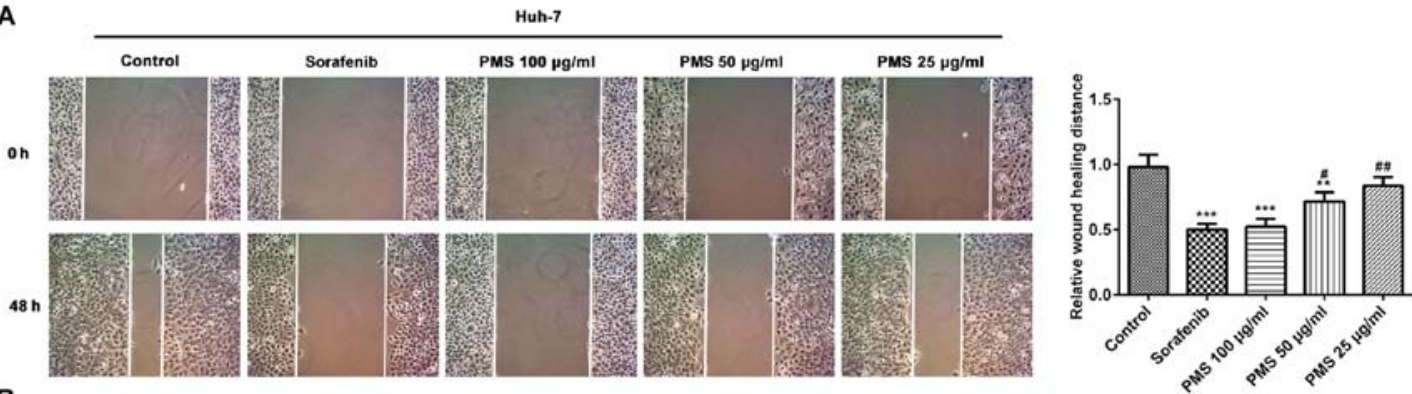

B
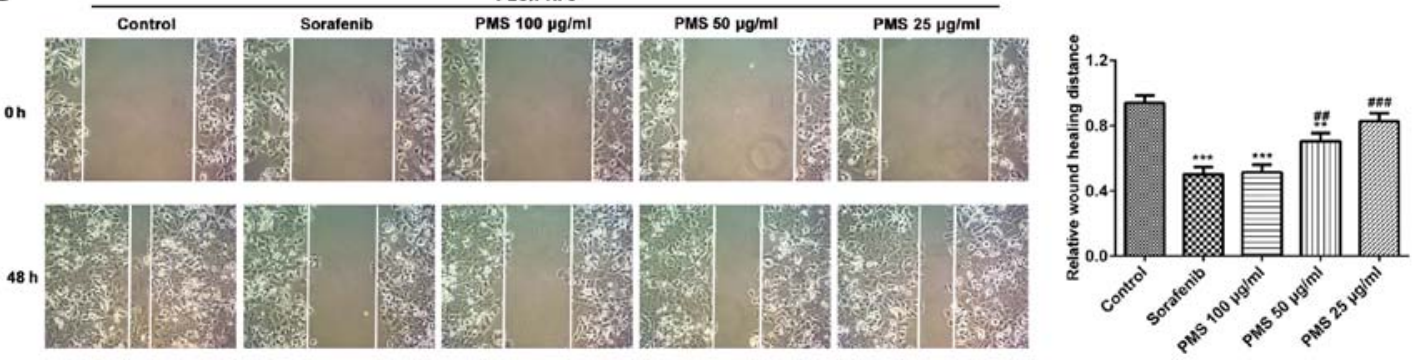

Figure 4. Cell migration is inhibited by PMS treatment. Wound healing assays were performed to detect the cell migration at $48 \mathrm{~h}$ in (A) Huh-7 and (B) PLC/PRF5 cells. Data are presented as the mean $\pm \mathrm{SD} .{ }^{* *} \mathrm{P}<0.01,{ }^{* * *} \mathrm{P}<0.001$ vs. the control group; ${ }^{\#} \mathrm{P}<0.05,{ }^{\# \#} \mathrm{P}<0.01,{ }^{\# \# \#} \mathrm{P}<0.001$ vs. sorafenib. PMS, plantamajoside.

A

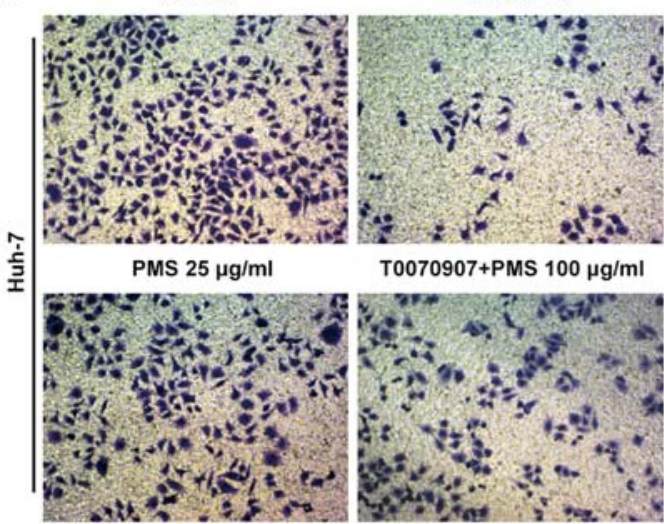

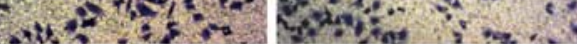
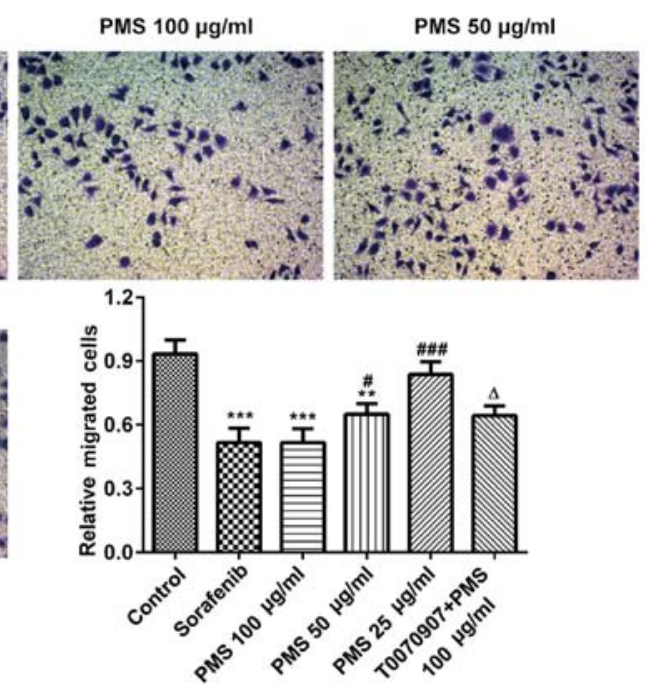

B Control Sorafenib PMS $100 \mu \mathrm{g} / \mathrm{ml}$ PMS $50 \mu \mathrm{g} / \mathrm{ml}$
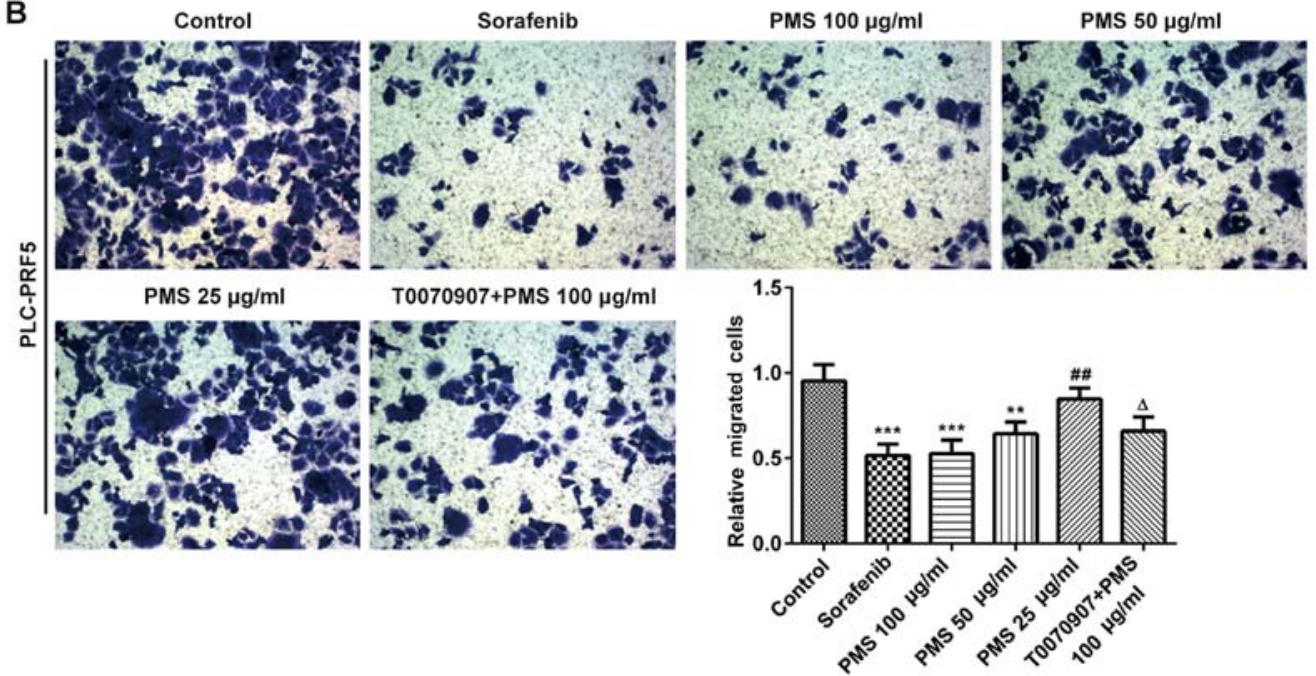

Figure 5. PMS inhibits cell migration through interactions with PPAR $\gamma$. Transwell assays was performed to investigate the effects of PMS on cell migration in (A) Huh-7 and (B) PLC/PRF5 cells. PPAR $\gamma$ inhibitor was used to reverse the effects of PMS. Sorafenib was used as a positive control and non-treated cells were used as a control. Data are presented as the mean $\pm \mathrm{SD} .{ }^{* *} \mathrm{P}<0.01,{ }^{* * * *} \mathrm{P}<0.001$ vs. the control group; ${ }^{*} \mathrm{P}<0.05,{ }^{\# \#} \mathrm{P}<0.01,{ }^{\# \# \|} \mathrm{P}<0.001$ vs. sorafenib; ${ }^{\wedge} \mathrm{P}<0.05$ vs. $\mathrm{PMS}$ $100 \mu \mathrm{g} / \mathrm{ml}$. PMS, plantamajoside; T0070907, PPAR $\gamma$ inhibitor. 
A
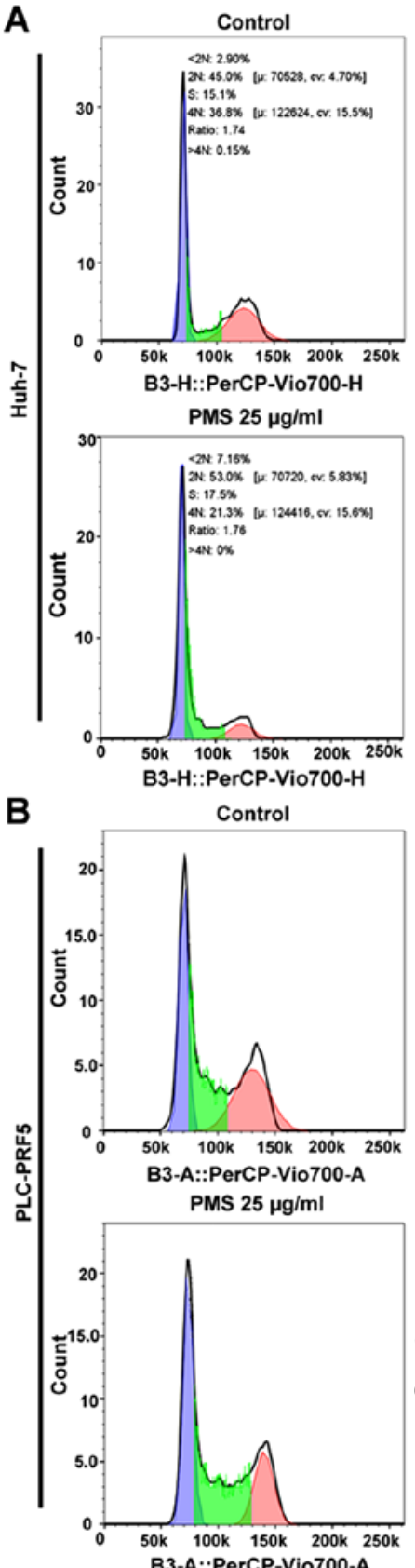

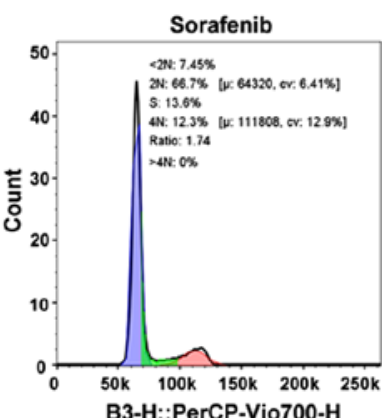

B3-H::PerCP-Vio700-H

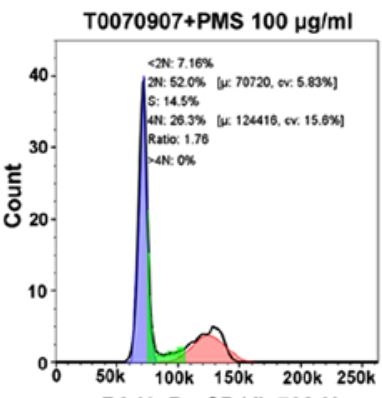

B3-H::PerCP-Vio700-H Sorafenib

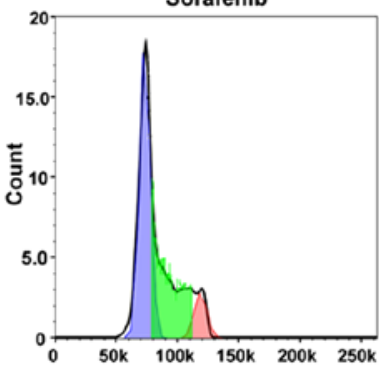

B3-A::PerCP-Vio700-A T0070907+PMS $100 \mu \mathrm{g} / \mathrm{ml}$

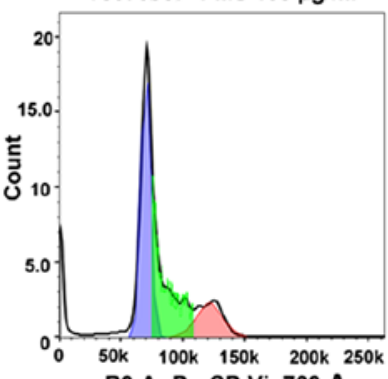

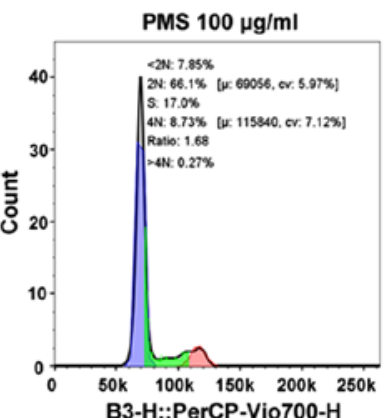

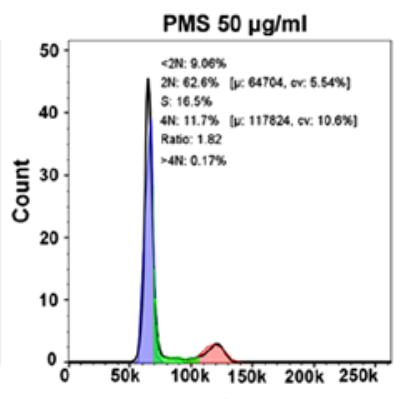

B3-H::PerCP-Vio700-H
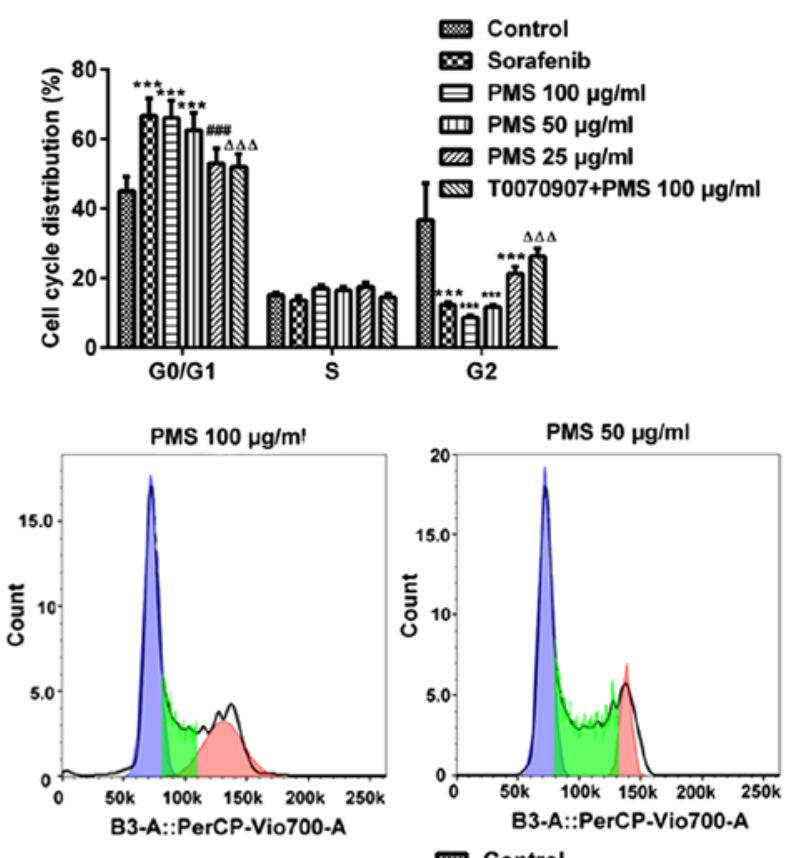

B3-A::PerCP-Vio700-A

Control

Sorafenib

曰PMS $100 \mu \mathrm{g} / \mathrm{ml}$

미 PMS $50 \mu \mathrm{g} / \mathrm{ml}$ ens PMS $25 \mu \mathrm{g} / \mathrm{ml}$ T0070907+PMS $100 \mu \mathrm{g} / \mathrm{m}$

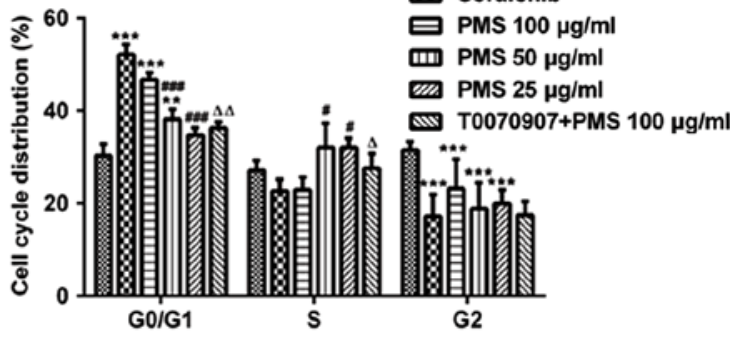

Figure 6. Cells are arrested in the G0/G1 phase after treatment with PMS and mediated by PPAR $\gamma$. PMS affects cell cycle progression through upregulating PPAR $\gamma$, as shown by flow cytometry in (A) Huh7 cells and (B) PLC/PRF5 cells. Sorafenib was used as a positive control and non-treated cells were used as a control. Data are presented as the mean $\pm \mathrm{SD}$. ${ }^{* *} \mathrm{P}<0.01,{ }^{* * *} \mathrm{P}<0.001$ vs. the control group; ${ }^{\#} \mathrm{P}<0.05$, ${ }^{\# \# \#} \mathrm{P}<0.001$ vs. sorafenib; ${ }^{\Delta} \mathrm{P}<0.05,{ }^{\Delta \Delta} \mathrm{P}<0.01$, ${ }^{\Delta \Delta \Delta} \mathrm{P}<0.001$ vs. PMS $100 \mu \mathrm{g} / \mathrm{ml}$. T0070907 was used for PPAR $\gamma$ inhibition. PMS, plantamajoside; PPAR $\gamma$, peroxisome proliferator-activated receptor $\gamma$.

treated cells compared with the control. The expression levels of Cyt- $\mathrm{C}$ were also increased in the sorafenib treated group, as well as in the PMS 100 and $50 \mu \mathrm{g} / \mathrm{ml}$ treated groups, compared with the control. Furthermore, the expression levels of both cleaved-caspase- 3 and $\mathrm{Cyt}-\mathrm{C}$ were significantly reversed by T0070907 treatment compared with the $100 \mu \mathrm{g} / \mathrm{ml}$ treated group, although this did not reach the levels of the control group.

PMS exerts its biological effects through the PPAR $/ N F-\kappa B /$ Cox-2 signaling pathway. Compared with the normal liver cell line THLE-2, the expression levels of PPAR $\gamma$ was significantly decreased, whereas that of Cox -2 and $N F-\kappa B$ was significantly increased in both untreated Huh7 and PLC/PRF5 cells. Western blotting analysis results revealed that the expression levels of NF- $\mathrm{NB}$ and Cox-2 were significantly decreased following treatment with sorafenib and high dose PMS $(100 \mu \mathrm{g} / \mathrm{ml})$, with no significant difference between the two groups. The intermediate $(50 \mu \mathrm{g} / \mathrm{ml})$ and low $(25 \mu \mathrm{g} / \mathrm{ml})$ PMS dose groups also exhibited a decrease in the expression of these proteins, but to a lesser degree compared with the high dose group, compared with the control group. PPAR $\gamma$ expression was increased in the sorafenib and PMS groups, with the effects of PMS appearing to be concentration-dependent. Inhibition of PPAR $\gamma$ significantly upregulated the expression of Cox-2 and NF- $\kappa \mathrm{B}$, compared with the PMS $100 \mu \mathrm{g} / \mathrm{ml}$ group (Fig. 9). 
A

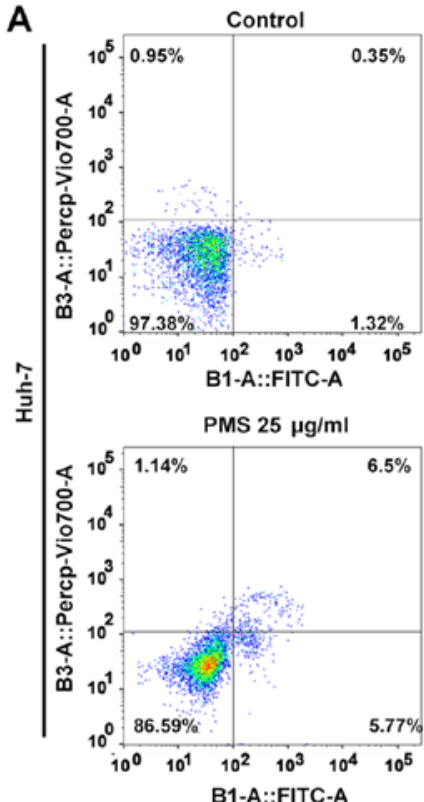

B1-A:FITC-A
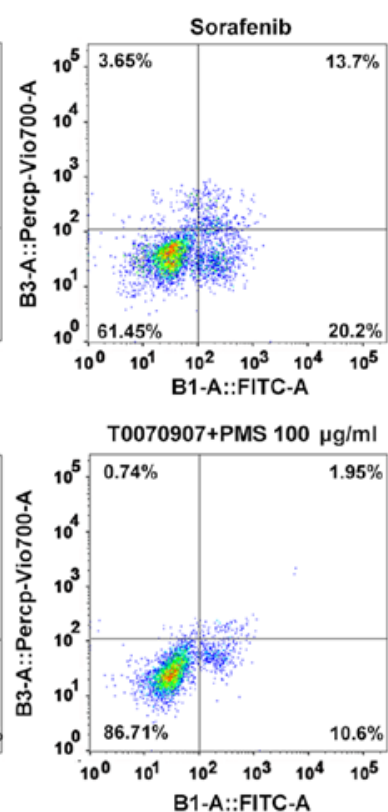

C
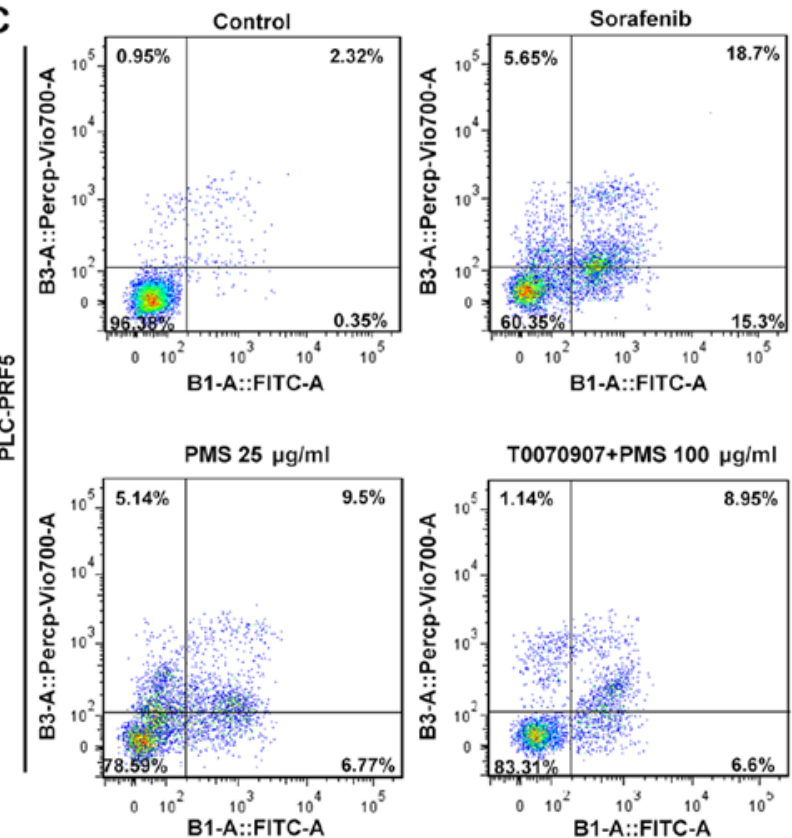
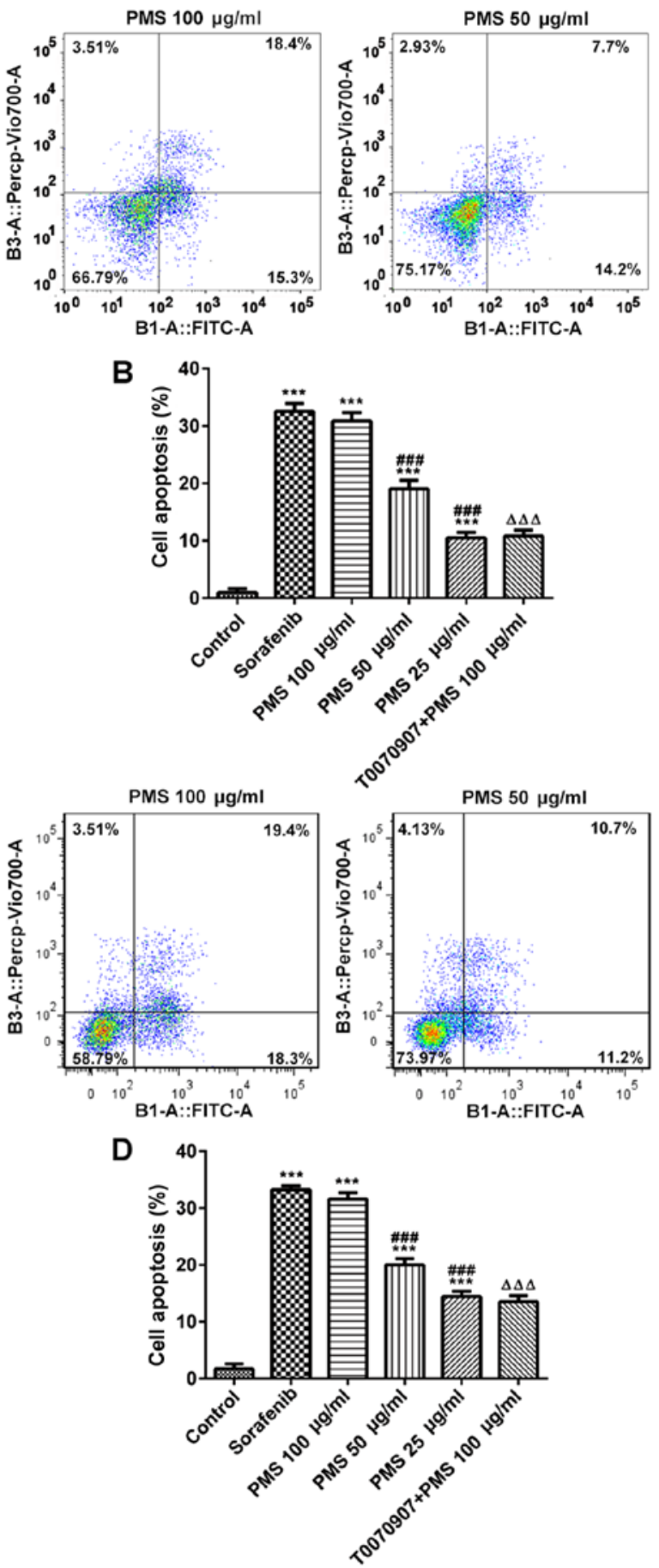

Figure 7. Cell apoptosis is promoted by PMS treatment and mediated by PPAR $\gamma$. Cell apoptosis was increased, as shown by flow cytometry, following PMS treatment. (A) Flow cytometry plots and (B) quantification in Huh7 cells, as well as (C) flow cytometry and (D) quantification in PLC/PRF5 cells. Sorafenib was used as a positive control and non-treated cells were used as a control. Data are presented as the mean $\pm \mathrm{SD} .{ }^{* * *} \mathrm{P}<0.001 \mathrm{vs}$. control; ${ }^{\# \# \#} \mathrm{P}<0.001 \mathrm{vs}$. sorafenib; ${ }^{\Delta \Delta \Delta} \mathrm{P}<0.001$ vs. PMS $100 \mu \mathrm{g} / \mathrm{ml}$. T0070907 was used for PPAR $\gamma$ inhibition. PMS, plantamajoside; PPAR $\gamma$, peroxisome proliferator-activated receptor $\gamma$.

\section{Discussion}

Herbal medicine is becoming increasingly attractive as a potential cancer therapy (23). PMS is extracted from Plantago major $\mathrm{L}$ which has been reported to exert inhibitory effects on certain types of cancer, such as breast cancer and esophageal squamous cell carcinoma $(13,14)$. However, the effect of PMS on HCC and the underlying mechanism of action remain unclear. It was hypothesized that PMS may be beneficial for the treatment of HCC.
To investigate this hypothesis, the biological effects of PMS on HCC cells were investigated. A high dose of PMS was found to significantly inhibit cell proliferation and migration, as well as to promote apoptosis. Sorafenib is used to prevent tumor relapses and metastasis in patients with HCC who undergo tumor resection (24). Sorafenib, a kinase inhibitor, is the only systemic treatment that is currently used to provide clinical improvements in patients with advanced HCC (25). As sorafenib is a useful treatment for advanced $\mathrm{HCC}$ and in most cases, liver cancer is discovered at a later 
A

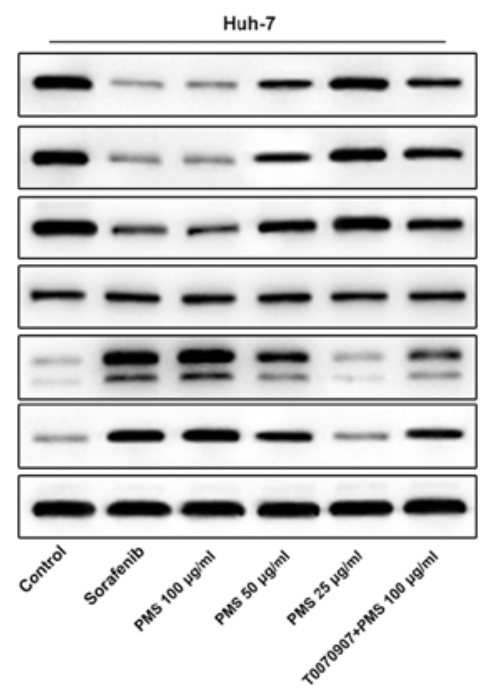

B
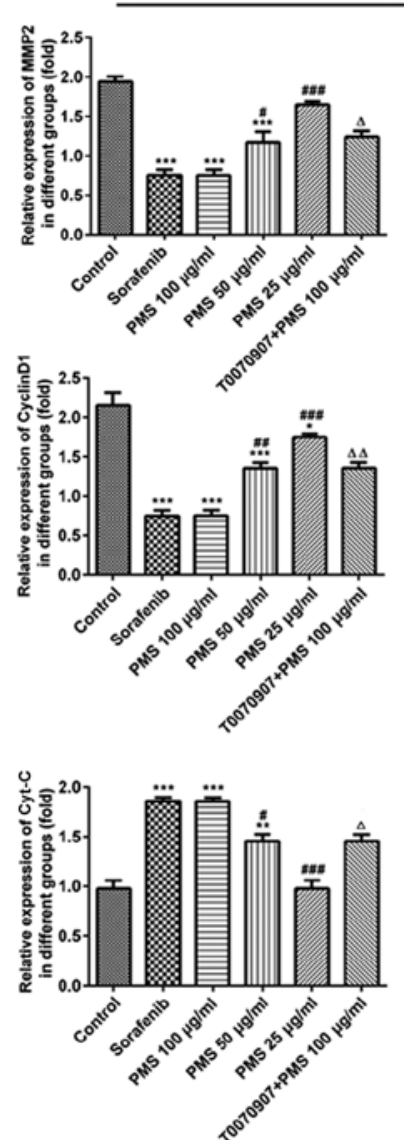

Huh-7

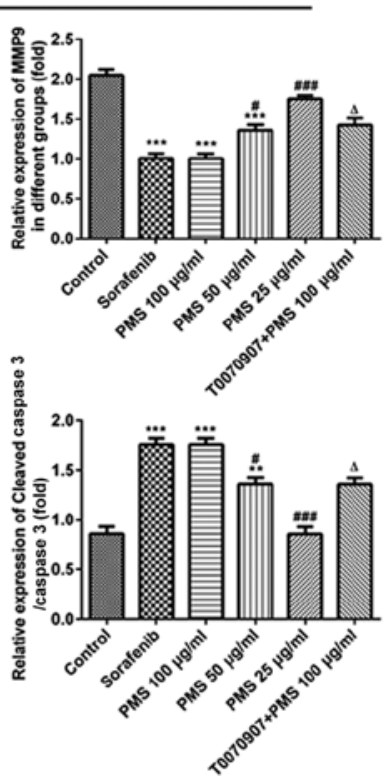

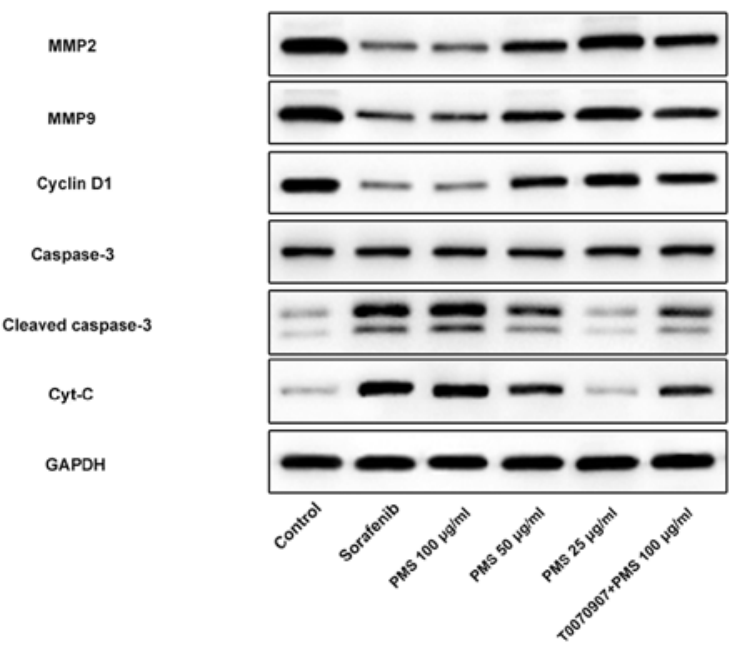

PLCIPRF5
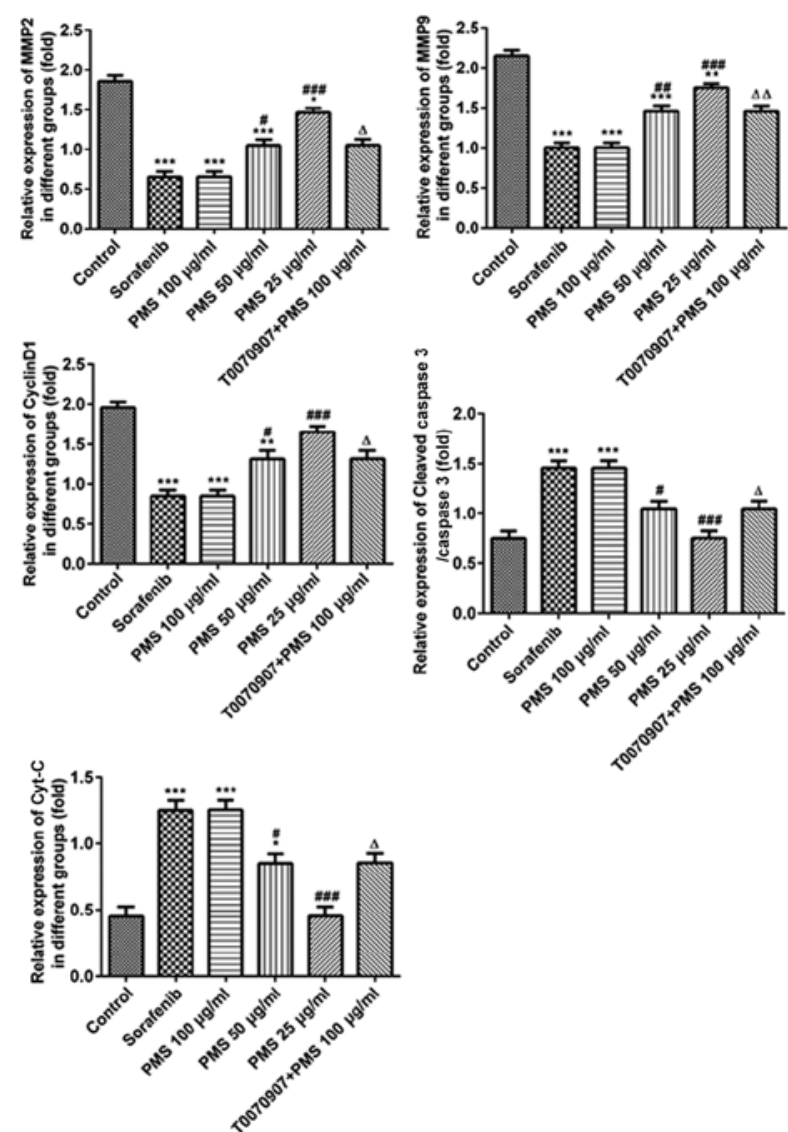

Figure 8. The role of PMS on cell proliferation, migration and apoptosis. The expression levels of proteins involved in migration (MMP2 and MMP9), apoptosis (caspase-3 and Cyt-C) and cell cycle (cyclin D1) were detected using (A) western blotting and (B) gray scan analysis from the Huh-7 can PLC/PRF5 cells following treatment with sorafenib, PMS and T0070907 + PMS. Data are presented as the mean $\pm \mathrm{SD}$. ${ }^{*} \mathrm{P}<0.05,{ }^{* * *} \mathrm{P}<0.01,{ }^{* * * *} \mathrm{P}<0.001$ vs. the control group; ${ }^{\# P} \mathrm{P}<0.05,{ }^{\# \#} \mathrm{P}<0.01,{ }^{\# \# \#} \mathrm{P}<0.001$ vs. sorafenib; ${ }^{\Delta} \mathrm{P}<0.05,{ }^{\Delta \Delta} \mathrm{P}<0.01$ vs. PMS $100 \mu \mathrm{g} / \mathrm{ml}$. T0070907 was used for PPAR $\gamma$ inhibition. Cyt-C, cytochrome C; MMP, matrix metalloproteinase; PMS, plantamajoside; PPAR $\gamma$, peroxisome proliferator-activated receptor $\gamma$.

stage, sorafenib was used as a control due to its proven efficacy (23). The present study herein demonstrated that a high dose of PMS exerted similar effects with the sorafenib positive control when inhibiting $\mathrm{HCC}$, indicating the potential role that PMS played on HCC cells in vitro.

It has previously been shown that PMS regulates cell migration, proliferation and apoptosis, and promotes the expression of PPAR $\gamma(13,14)$. To examine whether PPAR $\gamma$ was involved in these biological effects in HCC cells, HCC cells were pretreated with the PPAR $\gamma$ inhibitor, T0070907, before PMS treatment. PPAR $\gamma$ has been reported to inhibit MMP2 and MMP9, to exert an anti-tumor metastasis effect in mice with HCC $(26,27)$. Activation of PPAR $\gamma$ by its ligands are attributed to the suppression of proliferation and induction of apoptosis (28). The present results revealed that PPAR $\gamma$ mediated the effects of PMS on cell migration, proliferation 

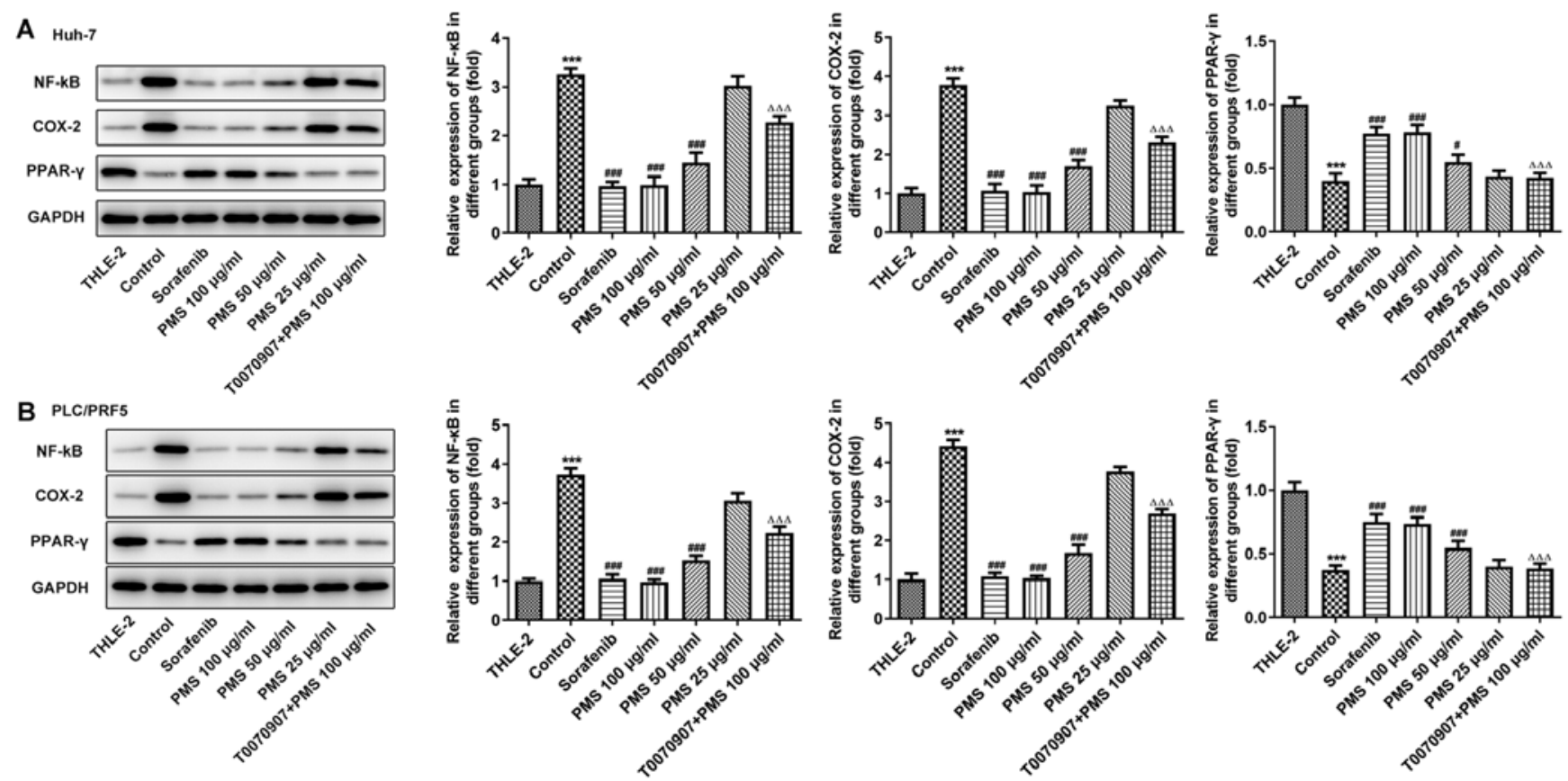

Figure 9. The biological activities of PMS are mediated through the PPAR $\gamma / \mathrm{NF}-\mathrm{\kappa B} / \mathrm{Cox}-2$ signaling pathway in hepatocellular carcinoma cell lines. The protein expression levels of PPAR $\gamma$, NF-кB and Cox-2 were detected using western blotting in (A) Huh-7 and (B) PLC/PRF5 cells as well as the normal liver cell line, THLE-2. Sorafenib was used as a positive control. Data are presented as the mean \pm SD. ${ }^{* * *} \mathrm{P}<0.001$ vs. THLE- 2 cells; ${ }^{*} \mathrm{P}<0.05$ and ${ }^{\# \# \#} \mathrm{P}<0.001$ vs. the control group; ${ }^{\Delta \Delta \Lambda} \mathrm{P}<0.001$ vs. PMS $100 \mu \mathrm{g} / \mathrm{ml}$. T0070907 was used for PPAR $\gamma$ inhibition. PMS, plantamajoside; PPAR $\gamma$, peroxisome proliferator-activated receptor $\gamma$; Cox-2, cyclooxygenase-2.

and apoptosis. Moreover, inhibition of PPAR $\gamma$ also blocked the expression levels of caspase-3 and Cyt-C, which were promoted by PMS. Cyt-C is a marker of the mitochondrial respiration chain (29), therefore, PMS may promote mitochondrial apoptosis in a PPAR $\gamma$-mediated manner. Cyclin D1 is a regulator of the progression from $\mathrm{G} 1$ to $\mathrm{S}$, as reflected by the accumulation in G1 (30). The present stdy showed that PMS inhibits cell proliferation and this effect is linked with the downregulation of cyclin D1 expression. In addition, T0070907 reversed the effects of PMS on cell proliferation.

In the present study, it was also observed that Cox-2 expression was significantly decreased following treatment with PMS, while PPAR $\gamma$ expression was significantly increased, and the two may have mutual constraints. PPAR $\gamma$ is a member of the ligand regulated nuclear receptor superfamily, which exerts diverse biological effects, such as promoting tumor cell growth, angiogenesis and invasion (31-33). PPAR $\gamma$ ligands can interact with Cox-2 and affect shared pathways. Previous studies have suggested that Cox-2 expression can be inhibited with PPAR $\gamma$ activators in human cervical cancer $(34,35)$. The dysregulation of the NF- $\kappa \mathrm{B}$ signaling pathway has recently been confirmed to be involved in the biological response to various types of cancer (36). NF- $\kappa B$ not only promotes tumor cell survival and protects cells against apoptotic stimuli, but may also promote proliferation and metastasis of tumor cells (37). The human Cox-2 promotor includes several transcription factor-binding sites, such as for NF- $\mathrm{KB}$ and NF-IL6 (34). It has been previously demonstrated that increased PPAR $\gamma$ expression inhibits the expression of Cox-2 and its promoter activity (38). In the present study, the expression of PPAR $\gamma$ was significantly promoted by PMS, whereas the expression of Cox- 2 and
NF- $\kappa \mathrm{B}$ was downregulated in Huh7 and PLC/PRF5 cells. Taken together, these findings indicated that PMS may have acted as an activator of the PPAR $\gamma / \mathrm{NF}-\kappa \mathrm{B} / \mathrm{Cox}-2$ signaling pathway in HCC cells.

In conclusion, the present study evaluated the effects of PMS on HCC cell metastasis, apoptosis, cell cycle distribution and proliferation. PMS was found to inhibit the proliferation and migration and promote the apoptosis of Huh7 and PLC/PRF5 cells. PMS also triggered G0/G1 phase arrest in Huh7 and PLC/PRF cells. The PPAR $\gamma / \mathrm{NF}-\mathrm{\kappa B} / \mathrm{Cox}-2$ axis may be the mechanism underlying its regulatory biological effects. These results indicated that PMS may be a promising agent for the treatment of HCC. However, more HCC cell lines as well as in vivo investigations should be explored in further research to confirm the findings of the present study.

\section{Acknowledgements}

Not applicable.

\section{Funding}

The present study was supported by the National Natural Science Foundation for Young Scientists of China (grant nos. 81703940 and 815503267).

\section{Availability of data and materials}

The datasets used and/or analyzed during the current study are available from the corresponding author on reasonable request. 


\section{Authors' contributions}

YL and SL conceived and designed the current study. SL, XJ, GY and YL acquired the data. ZL, LM, JW and HW analyzed the data. SL and YL drafted the manuscript and revised it for critically important intellectual content. All authors read and approved the final manuscript. YL and SL confirm the authenticity of all the raw data.

\section{Ethics approval and consent to participate}

Not applicable.

\section{Patient consent for publication}

Not applicable.

\section{Competing interests}

The authors declare that they have no competing interests.

\section{References}

1. Torre LA, Bray F, Siegel RL, Ferlay J, Lortet-Tieulent J and Jemal A: Global cancer statistics, 2012. CA Cancer J Clin 65: 87-108, 2015.

2. Jiang BG, Wang N, Huang J, Yang Y, Sun LL, Pan ZY and Zhou WP: Tumor SOCS3 methylation status predicts the treatment response to TACE and prognosis in HCC patients. Oncotarget 8: 28621-28627, 2017.

3. Guo XL, Li D, Hu F, Song JR, Zhang SS, Deng WJ, Sun K, Zhao QD, Xie XQ, Song YJ, et al: Targeting autophagy potentiates chemotherapy-induced apoptosis and proliferation inhibition in hepatocarcinoma cells. Cancer Lett 320: 171-179, 2012.

4. Tontonoz P and Spiegelman BM: Fat and beyond: The diverse biology of PPARgamma. Ann Rev Biochemistry 77: 289-312, 2008 .

5. Heudobler D, Rechenmacher M, Lüke F, Vogelhuber M, Pukrop T, Herr W, Ghibelli L, Gerner C and Reichle A: Peroxisome proliferator-activated receptors (PPAR) $\gamma$ agonists as master modulators of tumor tissue. Int J Mol Sci 19: 3540 , 2018.

6. Shen B, Chu ES, Zhao G, Man K, Wu CW, Cheng JT, Li G, Nie Y, Lo CM, Teoh N, et al: PPARgamma inhibits hepatocellular carcinoma metastases in vitro and in mice. $\mathrm{Br}$ J Cancer 106: 1486-1494, 2012

7. Yu J, Shen B, Chu ES, Teoh N, Cheung KF, Wu CW, Wang S, Lam CN, Feng H, Zhao J, et al: Inhibitory role of peroxisome proliferator-activated receptor gamma in hepatocarcinogenesis in mice and in vitro. Hepatology 51: 2008-2019, 2010.

8. Nojima H, Kuboki S, Shinoda K, Shimizu H, Ohtsuka M, Kato A, Yoshitomi H, Furukawa K, Takayashiki T and Miyazaki M: Activation of peroxisome proliferator-activated receptor-gamma inhibits tumor growth by negatively regulating nuclear factor- $\kappa \mathrm{B}$ activation in patients with hepatocellular carcinoma. J Hepatobiliary Pancreat Sci 23: 574-584, 2016.

9. Zhang N, Chu ES, Zhang J, Li X, Liang Q, Chen J, Chen M, Teoh N, Farrell G, Sung JJ and Yu J: Peroxisome proliferator activated receptor alpha inhibits hepatocarcinogenesis through mediating NF-kappaB signaling pathway. Oncotarget 5: 8330-8340, 2014.

10. Kern MA, Schoneweiss MM, Sahi D, Bahlo M, Haugg AM, Kasper HU, Dienes HP, Käferstein H, Breuhahn K and Schirmacher P: Cyclooxygenase-2 inhibitors suppress the growth of human hepatocellular carcinoma implants in nude mice. Carcinogenesis 25: 1193-1199, 2004.

11. Tsatsanis C, Androulidaki A, Venihaki M and Margioris AN: Signalling networks regulating cyclooxygenase-2. Int J Biochem Cell Biol 38: 1654-1661, 2006.
12. Wu H, Zhao G, Jiang K, Chen X, Zhu Z, Qiu C, Li C and Deng G: Plantamajoside ameliorates lipopolysaccharide-induced acute lung injury via suppressing NF- $\mathrm{KB}$ and MAPK activation. Int Immunopharmacol 35: 315-322, 2016

13. Pei S, Yang X, Wang H, Zhang H, Zhou B, Zhang D and Lin D: Plantamajoside, a potential anti-tumor herbal medicine inhibits breast cancer growth and pulmonary metastasis by decreasing the activity of matrix metalloproteinase- 9 and -2 . BMC Cancer 15: 965, 2015.

14. Li X, Chen D, Li M, Gao X, Shi G and Zhao H: Plantamajoside inhibits lipopolysaccharide-induced epithelial-mesenchymal transition through suppressing the NF- $\kappa$ B/IL-6 signaling in esophageal squamous cell carcinoma cells. Biomed Pharmacother 102: 1045-1051, 2018.

15. Han AR, Nam MH and Lee KW: Plantamajoside inhibits UVB and advanced glycation end products-induced MMP-1 expression by suppressing the MAPK and NF- $\kappa$ B pathways in HaCaT cells. Photochem Photobiol 92: 708-719, 2016.

16. Ma C and Ma W: Plantamajoside inhibits lipopolysaccharide-induced MUC5AC expression and inflammation through suppressing the PI3K/Akt and NF- $\kappa \mathrm{B}$ signaling pathways in human airway epithelial cells. Inflammation 41: 795-802, 2018.

17. Son WR, Nam MH, Hong CO, Kim Y and Lee KW: Plantamajoside from Plantago asiatica modulates human umbilical vein endothelial cell dysfunction by glyceraldehyde-induced AGEs via MAPK/NF- $\mathrm{BB}$. BMC Complement Altern Med 17: 66, 2017.

18. Lee G, Elwood F, McNally J, Weiszmann J, Lindstrom M, Amaral K, Nakamura M, Miao S, Cao P, Learned RM, et al: T0070907, a selective ligand for peroxisome proliferator-activated receptor gamma, functions as an antagonist of biochemical and cellular activities. J Biol Chem 277: 19649-19657, 2002.

19. Livak KJ and Schmittgen TD: Analysis of relative gene expression data using real-time quantitative PCR and the 2(-Delta Delta C(T)) method. Methods 25: 402-408, 2001.

20. Yao P, Li Y, Shen W, Xu X, Zhu W, Yang X, Cao J and Xing C: ANKHD1 silencing suppresses the proliferation, migration and invasion of CRC cells by inhibiting YAP1-induced activation of EMT. Am J Cancer Res 8: 2311-2324, 2018.

21. Tchakarska G and Sola B: The double dealing of cyclin D1. Cell Cycle 19: 163-178, 2020.

22. Kalpage HA, Bazylianska V, Recanati MA, Fite A, Liu J, Wan J, Mantena N, Malek MH, Podgorski I, Heath EI, et al: Tissue-specific regulation of cytochrome c by post-translational modifications: Respiration, the mitochondrial membrane potential, ROS, and apoptosis. FASEB J 33: 1540-1553, 2019.

23. Sarris J, Panossian A, Schweitzer I, Stough C and Scholey A: Herbal medicine for depression, anxiety and insomnia: A review of psychopharmacology and clinical evidence. Eur Neuropsychopharmacol 21: 841-860, 2011.

24. Feng YX, Wang T, Deng YZ, Yang P, Li JJ, Guan DX, Yao F, Zhu YQ, Qin Y, Wang H, et al: Sorafenib suppresses postsurgical recurrence and metastasis of hepatocellular carcinoma in an orthotopic mouse model. Hepatology 53: 483-492, 2011.

25. Llovet JM, Ricci S, Mazzaferro V, Hilgard P, Gane E, Blanc JF, de Oliveira AC, Santoro A, Raoul JL, Forner A, et al: Sorafenib in advanced hepatocellular carcinoma. N Engl J Med 359: 378-390, 2008

26. Han M, Gao H, Ju P, Gao MQ, Yuan YP, Chen XH, Liu KL, Han YT and Han ZW: Hispidulin inhibits hepatocellular carcinoma growth and metastasis through AMPK and ERK signaling mediated activation of PPAR $\gamma$. Biomed Pharmacother 103: 272-283, 2018.

27. Liu YI, Liu Z, Chen Y, Xu K and Dong J: PPAR $\gamma$ activation reduces ischemia/reperfusion-induced metastasis in a murine model of hepatocellular carcinoma. Exp Ther Med 11: 387-396, 2016

28. Takahashi N, Okumura T, Motomura W, Fujimoto Y, Kawabata I and Kohgo Y: Activation of PPAR $\gamma$ inhibits cell growth and induces apoptosis in human gastric cancer cells. FEBS Lett 455: 135-139, 1999.

29. Bock FJ and Tait SWG: Mitochondria as multifaceted regulators of cell death. Nature reviews. Mol Cell Biol 21: 85-100, 2020.

30. Bendris N, Lemmers B and Blanchard JM: Cell cycle, cytoskeleton dynamics and beyond: The many functions of cyclins and CDK inhibitors. Cell Cycle 14: 1786-1798, 2015. 
31. Niu Z, Shi Q, Zhang W, Shu Y, Yang N, Chen B, Wang Q, Zhao X, Chen J, Cheng N, et al: Caspase-1 cleaves PPAR $\gamma$ for potentiating the pro-tumor action of TAMs. Nat Commun 8: 766, 2017.

32. Zhao T, Du H, Blum JS and Yan C: Critical role of PPAR in myeloid-derived suppressor cell-stimulated cancer cell proliferation and metastasis. Oncotarget 7: 1529-1543, 2016.

33. Cheng J, Miao B, Hu KQ, Fu $X$ and Wang XD Apo-10'-lycopenoic acid inhibits cancer cell migration and angiogenesis and induces peroxisome proliferator-activated receptor $\gamma$. J Nutr Biochem 56: 26-34, 2018.

34. Ikawa H, Kameda H, Kamitani H, Baek SJ, Nixon JB, Hsi LC and Eling TE: Effect of PPAR activators on cytokine-stimulated cyclooxygenase- 2 expression in human colorectal carcinoma cells. Exp Cell Res 267: 73-80, 2001.

35. Han S, Inoue H, Flowers LC and Sidell N: Control of COX-2 gene expression through peroxisome proliferator-activated receptor gamma in human cervical cancer cells. Clin Cancer Res 9: 4627-4635, 2003.
36. Cildir G, Low KC and Tergaonkar V: Noncanonical NF- $\mathrm{B}$ signaling in health and disease. Trends Mol Med 22: 414-429, 2016.

37. Xiong S, Wang Y, Li H and Zhang X: Low dose of bisphenol a activates $N F-\kappa B / I L-6$ signals to increase malignancy of neuroblastoma cells. Cell Mol Neurobiol 37: 1095-1103, 2017.

38. Bren-Mattison Y, Meyer AM, Van Putten V, Li H, Kuhn K, Stearman R, Weiser-Evans M, Winn RA, Heasley LE and Nemenoff RA: Antitumorigenic effects of peroxisome proliferator-activated receptor-gamma in non-small-cell lung cancer cells are mediated by suppression of cyclooxygenase-2 via inhibition of nuclear factor-kappaB. Mol Pharmacol 73: 709-717, 2008

(c) (i) (9) This work is licensed under a Creative Commons Attribution-NonCommercial-NoDerivatives 4.0 International (CC BY-NC-ND 4.0) License. 